\title{
Changes in the non-protein thiol pool and production of Dissolved Gaseous Mercury in the marine diatom Thalassiosira weissflogii under mercury exposure
}

\author{
Elisabetta Morelli ${ }^{*}, \mathrm{a}$ Romano Ferrara ${ }^{\mathrm{a}}$, Barbara Bellini ${ }^{\mathrm{a}}$, Fernando Dini ${ }^{\mathrm{b}}$, Graziano Di \\ Giuseppe $^{\mathrm{b}}$ and Laura Fantozzi ${ }^{\mathrm{b}}$ \\ ${ }^{a}$ Istituto di Biofisica (CNR), Area della Ricerca di Pisa, Via Moruzzi 1, 56124 Pisa, Italy \\ ${ }^{b}$ Dipartimento di Biologia, Università di Pisa, Via A. Volta 4, 56126 Pisa, Italy
}

*Corresponding Author. Tel. +39-050-3152757; Fax: +39-050-3152760; E-mail:

elisabetta.morelli@pi.ibf.cnr.it

\begin{abstract}
Two detoxification mechanisms working in the marine diatom Thalassiosira weissfloggii to cope with mercury toxicity were investigated. Initially, the effect of mercury on the intracellular pool of non-protein thiols was studied in exponentially growing cultures exposed to sub-toxic $\mathrm{HgCl}_{2}$ concentrations. $\underline{T}$. weissfloggii cells responded by synthesizing metalbinding peptides, named phytochelatins (PCs), besides increasing the intracellular pool of glutathione and $\gamma$-glutamylcysteine $(\gamma$-EC). Intracellular $\mathrm{Hg}$ and $\mathrm{PC}$ concentrations increased with the $\mathrm{Hg}$ concentration in the culture medium, exhibiting a distinct dose-response relationship. However, considerations of the PCs-SH:Hg molar ratio suggest that also glutathione could be involved in the intracellular mercury sequestration. The time course of the non-protein thiol pool and $\mathrm{Hg}$ intracellular concentration shows that PCs, glutathione and $\gamma$-EC represent a rapid cellular response to mercury, although their role in $\mathrm{Hg}$ detoxification seems to lose importance at longer incubation times. The occurrence of a process of reduction of $\mathrm{Hg}$ (II) to $\mathrm{Hg}^{\circ}$ and subsequent production of dissolved gaseous mercury (DGM) was also investigated at lower $\mathrm{Hg}$ concentrations, at which the $\mathrm{PC}$ synthesis doesn't seem to be involved. The significant $(\mathrm{P}<0.01)$ correlation between the cellular density in solution and the production of DGM suggests that this diatom is capable of directly producing DGM, both in light and dark conditions. This finding has been confirmed by the absence of DGM production in the culture media containing formaldehyde-killed cells. Finally, the relationship between these two different pathways of $\mathrm{Hg}$ detoxification is discussed.
\end{abstract}

Keywords: dissolved gaseous mercury; mercury; non-protein thiols; phytochelatins; phytoplankton; Thalassiosira weissflogii

\section{Introduction}

Mercury is one of the most dangerous trace metals because it does not have recognized biological activity and its presence is widespread in the aquatic environment. Hence, aquatic 
microorganisms, which are the first levels of the food chain, have developed defence strategies to neutralize the toxic effects of this metal (Barkay et al., 2003; Perales-Vela et al., 2006). Many studies have demonstrated that phytoplankton species can respond to metal toxicity through the production of antioxidant compounds (Pinto et al., 2003) and intracellular metal-binding thiol peptides (Kawakami et al., 2006 and references therein reported). Glutathione and related peptides appear to be the major components of heavy metal detoxification in plants, algae and some yeast species. Glutathione is the main non-protein thiol in animals, plants and protists. It plays an important role in maintaining reducting conditions inside cells and in protecting plants from environmental stress, including oxidative damage and excess of xenobiotic organic compounds or heavy metals. The accumulation of heavy metals in marine microalgae induces the enzymatically-mediated synthesis of intracellular peptides, polymers of glutathione, named phytochelatins (PCs). PCs, with the structure of $(\gamma$-Glu-Cys)n-Gly $(n=2-11)$, are thiol-containing peptides implied in heavy metal detoxification, because of their capability to bind metal ions inside the cells (Grill et al., 1985; Cobbett, 2000). In vitro experiments have shown that PCs protect metal-sensitive enzymes from inactivation and restore the activity of metal-poisoned enzymes (Kneer and Zenk, 1992). Several studies have revealed that PC synthesis is activated both $\underline{\text { in vivo }}$ and in vitro by a wide range of metal ions, including $\mathrm{Cd}^{2+}, \mathrm{Cu}^{2+}, \mathrm{Pb}^{2+}, \mathrm{Ag}^{+}, \mathrm{Zn}^{2+}$ and $\mathrm{Hg}^{2+}$ (Gekeler et al., 1988; Rauser, 1995; Zenk, 1996). A considerable amount of literature has been published on the induction of PCs in phytoplankton exposed to different metals like $\mathrm{Cd}, \mathrm{Pb}, \mathrm{Zn}, \mathrm{Cu}$ (Ahner et al., 1995; Morelli and Scarano 2001, 2004; Rijstenbil and Wijnholds, 1996; Le Faucheur et al., 2006) but the detoxification of mercury by PCs has been scarcely documented (Howe and Merchant, 1992; Ahner and Morel, 1995).

In recent years a number of investigations have focused on a detoxification mechanism acting in microorganisms exposed to mercury, that is the ability of bacteria to reduce $\mathrm{Hg}$ (II) to 
volatile $\mathrm{Hg}^{\circ}$ by means of an enzymatic pathway (Barkay et al., 1991; Nakamura et al., 2001; Rolfhus and Fitzgerald, 2004; Barkay and Wagner-Dobler, 2005; Fantozzi et al., 2009). In contrast, so far, few studies report the formation of $\mathrm{Hg}^{\circ}$ in phytoplanktonic algae (Ben-Bassat and Mayer, 1977; Mason 1995; Devars et al., 2000) and, in addition, this reduction mechanism is largely unknown. It is well known that elemental mercury $\left(\mathrm{Hg}^{\circ}\right)$ plays a fundamental role in the biogeochemical cycle of mercury (Schroeder et al., 1989; Horvat et al., 2003) since it constitutes $90 \%$ of volatile forms of mercury in natural waters, named Dissolved Gaseous Mercury (DGM). These forms pass from the water into the atmosphere due to their low water solubility and high volatility. The increasing interest in the study on the occurrence of a biotic production of DGM in aquatic environments, suggests that this issue needs to be further investigated.

Field and laboratory studies suggest that, besides bacteria, phytoplankton can play an important role in the processes of the formation of DGM, through an indirect contribution due to the release of biogenic organic matter involved in the photochemical reactions of DGM production, as well as through a cellular direct reduction (Mason et al., 1995; Devars et al., 2000; Lanzillotta et al., 2004; Poulain et al., 2004).

The aim of the present work is to investigate the defence mechanisms against mercury stress in the marine diatom Thalassiosira weissflogii by following the pattern of the non-protein thiol pool as well as the production of DGM. In particular, we investigated the intracellular concentration of glutathione, $\gamma$-EC and PCs as a function of both external metal concentration and time of exposure. In addition, we measured the production of $\mathrm{Hg}^{\circ}$ in a culture of the same diatom grown in a medium enriched with $\mathrm{HgCl}_{2}$, in dark and light conditions, in order to evaluate the mercury production process acting in this diatom.

\section{Materials and methods}




\section{$\underline{2.1 \text { Chemicals }}$}

All reagents were analytical grade: diethylenetriaminepentacetic acid (DTPA), reduced glutathione (GSH), $\gamma$-glutamylcysteine $(\gamma$-EC), cysteine and monobromobimane $(\mathrm{mBrB})$ were from Fluka; 4-(2-hydroxyethyl)-piperazine-1-propane-sulfonic acid (HEPPS), tris (2carboxyethyl) phosphine (TCEP), hydrogen peroxide (30\% solution) and $\mathrm{HgCl}_{2}$ were from Sigma; methanesulfonic acid (MSA) was from Merck; $\mathrm{HCl}, \mathrm{HNO}_{3} \mathrm{Suprapur}_{\text {grade, }}$ acetonitrile, trifluoroacetic acid (TFA), $\mathrm{SnCl}_{2}$ and formaldehyde (40\%) were from Carlo Erba. Solutions of $\mathrm{mBrB}, \mathrm{SnCl}_{2}$ and TCEP were prepared weekly. The solution of $\mathrm{SnCl}_{2}(0.4 \mathrm{M})$ in 1.2 $\mathrm{M} \mathrm{HCl}$ was purged with charcoal-filtered air for $1 \mathrm{~h}$ in order to provide a mercury-free solution. All the reagents were stored in the dark at $+4^{\circ} \mathrm{C}$. Water was purified by a Milli-Q system (Millipore).

Seawater was collected in an uncontaminated area, 3 miles offshore from the Island of Capraia (Tyrrhenian Sea, Italy), by a metal-clean technique, filtered through $0.45 \mu \mathrm{m}$ membrane filters and stored in the dark at $+4^{\circ} \mathrm{C}$.

Membrane filters used throughout the experiments were from Millipore.

\section{$\underline{2.2 \text { Culture conditions and molecular characterization }}$}

The marine diatom, Thalassiosira weissflogii (Grunow) Fryxell \& Hasle (1977) used in this study (strain 1085/1 isolated from Gorleston-on-Sea, Norfolk, England in 1975) was obtained from the Culture Collection of Algae and Protozoa (CCAP), Dunstaffnage Marine Laboratory, UK (http://www.ccap.ac.uk). Stock cultures were grown in axenic conditions, in natural seawater enriched with the f/2 medium (Guillard, 1975) at one-fifth the reported trace metal concentration, at $21^{\circ} \mathrm{C}$ and fluorescent daylight $\left(100 \mu \mathrm{mol}\right.$ photons $\left.\times \mathrm{m}^{-2} \times \mathrm{s}^{-1}\right)$ in a 16:8 light-dark cycle. Exponential growth was maintained by inoculating cells into a fresh 
sterilized medium, weekly. Cell counts were carried out by means of a Neubauer counting chamber under a microscope.

Since molecular clades of diatoms are often cryptic, with no or few morphological or life history traits that can be convincingly argued to be synapomorphies, we carried out a molecular characterization of the diatom strain used in this study. The DNA was isolated following the standard protocol of Sambrook et al. (1989), modified and optimized for the genomic DNA isolation from protists, as reported by Fokin et al. (2008). The SSU-rRNA gene, universally considered a good species-specific marker, was amplified by PCR using the universal eukaryotic forward primer 18S F9 5'-CTGGTTGATCCTGCCAG-3' (Medlin et al., 1988) and the 18S R1513 Hypo reverse primer 5'-TGATCCTTCYGCAGGTTC-3' (Petroni et al., 2002). The PCR product was purified and directly sequenced in both directions. The SSU-rRNA gene sequence of the $\underline{T}$. weissflogii strain used in this study is available from the GenBank/EMBL databases under the accession number FJ600728.

\section{$\underline{2.3 \text { Incubation experiments }}$}

All the mercury incubation experiments were carried out using, as a culture medium, natural seawater enriched with the $\mathrm{f} / 2$ medium lacking the trace metal stock solution. Calculated volumes of the stock cultures of $\underline{T}$. weissflogii, at the end of the logarithmic growth phase, were used as inoculum to obtain an initial cell density of $1 \times 10^{6}$ cells $\mathrm{L}^{-1}$. In a first set of incubation experiments, designed to evaluate the effect of mercury on the growth rate of $\underline{\mathrm{T} \text {. weissflogii }}, 100 \mathrm{~mL}$ culture media were spiked with $\mathrm{HgCl}_{2}$ to the final concentrations ranging from 5 to $750 \mathrm{nM}$. The cultures were allowed to grow for 6 days during the exponential phase and the growth was monitored by counting cells. Two different experiments were carried out, with the aim of investigating the pattern of the non-protein thiol pool under mercury exposure. In a 2-day exposure experiment, 1-L cultures 
were exposed to $\mathrm{HgCl}_{2}$ concentrations ranging from 5 to $150 \mathrm{nM}$. At the end of the exposure (cell density was $1-2 \times 10^{7}$ cells $\mathrm{L}^{-1}$ ), aliquots of $800 \mathrm{~mL}$ and $50 \mathrm{~mL}$ of each culture were used for the determination of the non-protein thiols and the intracellular mercury concentration $\left([\mathrm{Hg}]_{\text {intr }}\right)$, respectively. In a 7-day exposure experiment, a 2-L culture was exposed to $150 \mathrm{nM} \mathrm{HgCl}_{2}$ and, at selected time intervals, from 0 to 7 days, aliquots of $50 \mathrm{~mL}$ of the culture were sampled and used for the determination of the $[\mathrm{Hg}]_{\text {intr. }}$. Moreover, aliquots of the culture from 800 to $200 \mathrm{~mL}$, depending on cell density, were sampled and used for the determination of the non-protein thiols. In the exposure experiments, a control culture (no $\mathrm{Hg}$ added) was always used.

The production of dissolved gaseous mercury (DGM) was measured in cultures of $\underline{T}$. weissflogii during exponential growth. For this purpose, $500-\mathrm{mL}$ of the culture medium was spiked with $\mathrm{HgCl}_{2}$ to reach an initial concentration of $5 \mathrm{nM}$ and left to stand for 3 days. Before cell addition, the concentration of total dissolved mercury was approximately $65 \%$ of the initial one. This procedure was chosen to avoid elevated abiotic DGM production occurring within the first days after mercury addition, as shown in preliminary experiments. After inoculum of $\underline{T}$. weissflogii cells, two aliquots of $50 \mathrm{~mL}$ of the culture were sampled at 1 day time intervals and used for the measurement of the DGM production and for the determination of the cellular mercury concentration $\left([\mathrm{Hg}]_{\text {cell }}\right)$, respectively. An additional experiment of DGM production was performed by using $\underline{T}$. weissflogii cells treated with formaldehyde according to the following procedure. Mercury-treated cells from $50 \mathrm{~mL}$ of a culture at the $4^{\text {th }}$ day of growth (cell density approx. $4-5 \times 10^{7}$ cell $\mathrm{L}^{-1}$ ) were collected by filtration $(1.2 \mu \mathrm{m}$ membrane filters) and re-suspended for $10 \mathrm{~min}$ in a solution of $1.6 \%$ formaldehyde in seawater. Afterwards, the formaldehyde-killed cells were collected by filtration, re-suspended again in their growth medium and submitted to the measurement of DGM production. 


\section{$\underline{2.4 \text { Determination of total dissolved mercury }}$}

Total dissolved mercury concentration $\left([\mathrm{Hg}]_{\text {diss }}\right)$ was determined in the culture medium

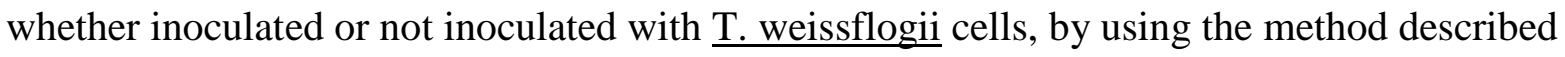
elsewhere (Ferrara et al., 2001). In the former culture medium, the cells were removed by filtration $(1.2 \mu \mathrm{m}$ membrane filters $)$ before the $\mathrm{Hg}$ measurement. A calculated aliquot of the sample was diluted with distilled water to a final volume of $25 \mathrm{~mL}$, acidified with $100 \mu \mathrm{L}$ of $\mathrm{HNO}_{3}$ and photo-oxidized using a UV medium-pressure lamp (90W) for 5 minutes in an ice bath. Mercury was measured using the Atomic Absorption Spectrometer (AAS) Gardis-3, based on the dual gold amalgamation procedure, after adding $200 \mu \mathrm{L}$ of the $\mathrm{SnCl}_{2}$ solution and purging with mercury-free air for $3 \mathrm{~min}$ at a flow rate of $0.3 \mathrm{~L} \mathrm{~min}^{-1}$.

\section{$\underline{2.5 \text { Determination of cellular and intracellular mercury concentration }}$}

Mercury-treated cells were collected by filtration onto $1.2 \mu \mathrm{m}$ membrane filters and used for the determination of the total cellular mercury concentration $\left([\mathrm{Hg}]_{\text {cell }}\right)$. In order to determine the $[\mathrm{Hg}]_{\text {intr }}$, the harvested cells were incubated for 10 minutes with $1 \mathrm{mM}$ EDTA in seawater to remove the metal adsorbed to the cell surface, then rinsed extensively with natural seawater. The cells, whether rinsed with EDTA or not rinsed, were immediately placed in 1 mL of $\mathrm{HNO}_{3}(0.14 \mathrm{M})$ in water and mixed with $1 \mathrm{~mL}$ of concentrated $\mathrm{HNO}_{3}$ and $\mathrm{H}_{2} \mathrm{O}_{2}(2: 1$ $\mathrm{v} / \mathrm{v})$. The sample was digested at $45^{\circ} \mathrm{C}$ for $16 \mathrm{~h}$. This mineralization procedure was validated by using a Standard Reference Material (T6) "Fresh Water Plankton". The results of analysis

on the Standard Reference Material was $0.173 \pm 0.03 \mu \mathrm{g} \mathrm{g}^{-1} \mathrm{DW}$, compared with that of 0.186 $\pm 0.04 \mu \mathrm{g} \mathrm{g}^{-1} \mathrm{DW}$ reported by JRC (Joint Research Centre) of the European Commission. A calculated aliquot of the mineralized sample was diluted with distilled water to a final volume 
of $25 \mathrm{~mL}$, added with $200 \mu \mathrm{L}$ of the $\mathrm{SnCl}_{2}$ solution and assayed for mercury concentration by pre-concentration on a gold trap and AAS determination.

\subsection{Determination of DGM production}

Measurements of the DGM production under both dark and light conditions were accomplished using the experimental apparatus described in detail elsewhere (Fantozzi et al., 2009).

A $50 \mathrm{~mL}$ sample was transferred into a $100 \mathrm{~mL}$ glass Pyrex purging bottle, showing optical properties elsewhere described (Lanzillotta and Ferrara, 2001) and a good transmittance $(85 \%)$ for wavelengths $>350 \mathrm{~nm}$.

Prior to the determination of the DGM production, samples were purged for 2 hours in dark conditions in order to eliminate the original DGM content.

DGM production in darkness was obtained incubating the sample contained in the purging bottle for $20 \mathrm{~min}$ in the dark; DGM production under light conditions was recorded following the exposure of the purging bottle, containing the sample, for $20 \mathrm{~min}$ to the same fluorescent light used for culture growth $\left(100 \mu \mathrm{mol}\right.$ photons $\left.\times \mathrm{m}^{-2} \times \mathrm{s}^{-1}\right)$.

The DGM produced in the sample was extracted under dark conditions by means of mercurypurified air, used as a carrier gas, and accumulated on a gold trap. Mercury was thermally desorbed heating the trap at $500{ }^{\circ} \mathrm{C}$ and determined by Atomic Fluorescence Spectrometry (Tekran 2500 - detection limit $5 \times 10^{-4}$ pmol $\mathrm{Hg}$ ), using pure argon as a carrier gas. The detection limit of the procedure was $0.05 \mathrm{pM}$, calculated on the basis of the three standard deviation of the blank. The instrument was calibrated using a $25 \mu \mathrm{L}$ Hamilton gas-tight micro-syringe to inject elemental mercury saturated air from a mercury vapour generator, kept at a constant temperature $\left(4{ }^{\circ} \mathrm{C}\right)$, onto the gold trap. Preliminary tests were performed to verify the period of incubation within which the DGM production was linear in time. An 
incubation time of 20 minutes was selected to obtain a meaningful DGM amount and to be within the linear time range of DGM production.

All the experiments were performed at a constant temperature of $21^{\circ} \mathrm{C}$ and the purging bottle, together with the Teflon tubing, were pre-cleaned by acid washing every time before the experimental apparatus was involved in a new measurement cycle.

The DGM determinations were replicated 3 times.

\section{$\underline{2.7 \text { Determination of the non-protein thiols }}$}

After incubation, the cells were collected by filtration onto $1.2 \mu \mathrm{m}$ membrane filters, resuspended in $1.5 \mathrm{~mL}$ of $0.1 \mathrm{M} \mathrm{HCl} / 5 \mathrm{mM}$ DTPA, then disrupted by sonication (Sonopuls Ultrasonic Homogenizer, Bandelin) for 3 min with a repeating duty cycle of $0.3 \mathrm{~s}$, in an ice bath. The cellular homogenate was centrifuged (20000 g, $45 \mathrm{~min})$ and the supernatant was used for the determination of thiols. Glutathione, $\gamma$-EC and PCs were separated and quantified by High Performance Liquid Chromatography (HPLC) after derivatization with the fluorescent tag $\mathrm{mBrB}$, by following the procedure described elsewhere (Morelli and Scarano, 2001), based on the method reported by Rijstenbil and Wijnholds (1996) with some modifications. Briefly, $400 \mu \mathrm{L}$ of the sample were added to $200 \mu \mathrm{L}$ of buffer $(400 \mathrm{mM}$ HEPPS / $5 \mathrm{mM}$ DTPA, $\mathrm{pH}$ 9) and to $20 \mu \mathrm{L}$ of $10 \mathrm{mM}$ TCEP in order to reduce oxidized thiol groups. After 15 min of incubation, two successive reactions in the dark at $45^{\circ} \mathrm{C}$ for $15 \mathrm{~min}$ were carried out, following the addition of $40 \mu \mathrm{L}$ of $10 \mathrm{mM} \mathrm{mBrB}$ and of $40 \mu \mathrm{L}$ of $100 \mathrm{mM}$ cysteine, respectively. Finally, $40 \mu \mathrm{L}$ of $1 \mathrm{M}$ MSA were added to stop the reaction. Analyses were performed on an HPLC system consisting of two Shimadzu LC-10AD pumps, a Rheodyne 7725 injection valve equipped with a $100 \mu \mathrm{L}$ loop, a fluorescence detector (RF10AXL, Shimadzu) set at $380 \mathrm{~nm}$ excitation wavelength and $470 \mathrm{~nm}$ emission wavelength, and an Alltech Alltima $(5 \mu \mathrm{m}, 250 \mathrm{~mm} \times 4.6 \mathrm{~mm}) \mathrm{C}-18$ reverse-phase column. An acetonitrile 
gradient in $0.1 \%$ TFA (from $10 \%$ to $12 \%$ for $15 \mathrm{~min}$ and from $12 \%$ to $28 \%$ for a further 40 min) was used at a flow rate of $1 \mathrm{~mL} \min ^{-1}$. Standard PCs from Silene vulgaris (Friederich et al., 1998) were kindly provided by Prof. M.H. Zenk, Munich University (Germany), and were used to check the retention time of phytochelatin oligomers. PC quantification was obtained from the relationship peak area vs concentration of GSH standard solutions. The total cellular PC concentration was expressed as the sum of the $\gamma$-Glu-Cys units quantified in each chromatographic peak of phytochelatins.

\section{Results}

\subsection{Effect of mercury exposure on the growth rate of T. weissflogii}

The effect of mercury on the growth rate $(\mu)$ of $\underline{T}$. weissflogii was investigated by growing cells in culture media at increasing $\mathrm{Hg}$ concentrations (initial cell density $1 \times 10^{6}$ cell $\mathrm{L}^{-1}$ ). The growth rate of the control culture was about $1.0 \pm 0.1$ doublings day $^{-1}(n=3)$. In the range of $\mathrm{Hg}$ from 5 to $500 \mathrm{nM}$ the growth rate gradually decreased, reflecting the inhibition of growth under mercury exposure (Fig. 1). Exponential growth was observed in all the cultures during 6 day exposure, but the $\mathrm{Hg}$ addition lengthened the lag phase, as also reported by other authors for cultures of Chlorella (Ben-Bassat and Mayer, 1975). It was extrapolated that the $50 \%$ inhibition of the growth rate occurred at an initial $[\mathrm{Hg}]=250 \mathrm{nM}$, whereas inhibitions lower than $20 \%$ occurred for $[\mathrm{Hg}] \leq 150 \mathrm{nM}$. In order to avoid toxic effects during mercury exposure, we used well tolerated $\mathrm{Hg}$ dosages, never exceeding the dose of $150 \mathrm{nM}$ in the exposure experiments.

\section{$\underline{3.2 \text { Two-day exposure to mercury }}$}

The pattern of the non-protein thiol pool in response to mercury exposure was studied by monitoring the concentration of glutathione, $\gamma$-EC and PCs in cells of $\underline{\mathrm{T} \text {. weissflogii exposed }}$ 
for 2 days to increasing $\mathrm{Hg}$ concentrations, from 5 to $150 \mathrm{nM}$ (Fig. 2). T. weissflogii cells responded to the $\mathrm{Hg}$ exposure by increasing the total level of the non-protein thiol pool. Glutathione was the major thiol, being always present at concentrations higher than those of $\gamma$-EC and PCs. Its intracellular concentration increased even at low $\mathrm{Hg}$ concentrations. At 150 $\mathrm{nM} \mathrm{Hg}$, the amount of glutathione was two-fold with respect to that found in the non-treated cells. The concentration of $\gamma$-EC was significantly less than that of glutathione both in the control and in Hg-treated cells, but its level increased with increasing $\mathrm{Hg}$ concentration in solution. Hg exposure also induced the synthesis of PCs but, under these experimental conditions, they were detectable at $[\mathrm{Hg}] \geq 25 \mathrm{nM}$. The PC cellular pool increased by following a dose-response relationship until it reached the value of $673 \pm 104 \mathrm{amol} \mathrm{cell}^{-1}$ at $150 \mathrm{nM} \mathrm{Hg}$. The cellular pool of peptides was composed mainly of $\mathrm{PC}_{2}(85-100 \%)$, the remaining amount being polymerized as $\mathrm{PC}_{3}(0-15 \%)$. The predominance of the pentapeptide and the inability to synthesize oligomers with $n>3$ were found in all the cultures, irrespectively of the $\mathrm{Hg}$ dose. Assays of intracellular $\mathrm{Hg}$ showed that the metal concentration $\left([\mathrm{Hg}]_{\text {intr }}\right)$ increased with the $\mathrm{Hg}$ exposure, exhibiting a trend similar to that of the PCs. Cellular concentration of thiol groups of PCs was similar to that of intracellular $\mathrm{Hg}$, exhibiting a molar ratio $\mathrm{PCs}-\mathrm{SH}: \mathrm{Hg}$ close to 1 . Since in vitro studies have shown that $\mathrm{PC}_{2}$ binds $\mathrm{Hg}$ with a stoichiometry of two SH groups for one metal ion (Mehra et al., 1996), it seems that the amount of PCs synthesized in this diatom during a 2-day exposure is not sufficient to sequester intracellular mercury ions. The finding that cellular glutathione and, to a lesser extent, $\gamma$-EC increased in response to $\mathrm{Hg}$ exposure, can account for a role in the intracellular mercury sequestration, in addition to PCs.

\section{$\underline{3.3 \text { Time course of the non-protein thiol pool and mercury accumulation }}$}




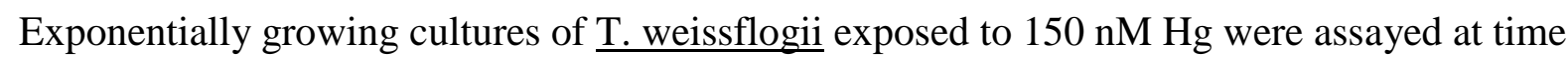
intervals for their intracellular concentration of $\mathrm{Hg}$ and non-protein thiols (Fig. 3). The time course of the $[\mathrm{Hg}]_{\text {intr }}$ showed a rapid uptake of the metal, occurring during the first day of exposure, thereafter there was no further increase at longer exposures. The PC cellular concentration, after reaching a maximum value on the first day, decreased with exposure time, until halved at the $7^{\text {th }}$ day of exposure. This finding indicates that PC synthesis occurs quickly, as soon as the metal is taken up by the cells, thereafter, the lowering of its concentration suggests the occurrence of a process of degradation and/or export, as reported by other authors for Cd-PCs complexes induced in the same diatom (Lee et al., 1996). Glutathione assays showed a transient increase of its intracellular concentration in the $\mathrm{Hg}$ treated cells compared to that measured in the control culture, occurring during the first 2 days of exposure. An increase of 65 and $137 \%$ was calculated on the $1^{\text {st }}$ and $2^{\text {nd }}$ day, respectively. At the end of the experiment, the glutathione level in the Hg-treated cells was restored to values similar to those of the untreated cells. A similar pattern was observed for the $\gamma \mathrm{EC}$ peptides, which exhibited an increase in the Hg-treated cells compared to the untreated ones of 145 and $103 \%$ on the $1^{\text {st }}$ and $2^{\text {nd }}$ day, respectively. In conclusion, the time course of the non-protein thiol pool and $\mathrm{Hg}$ intracellular concentration shows that PCs, glutathione and $\gamma$-EC represent a rapid cellular response to mercury. However, at longer incubation times, their role in $\mathrm{Hg}$ detoxification seems to lose importance. Since the $[\mathrm{Hg}]_{\text {intr }}$ remained almost constant during the entire incubation time, and the PC concentration lowered, it can be hypothesized that part of the intracellular Hg initially sequestered by PCs, or possibly by glutathione and $\gamma$-EC, could be transferred to other, more stable intracellular ligands.

Similar incubation experiments carried out at lower $\mathrm{Hg}$ concentrations, at which the PC synthesis doesn't seem to be involved, showed that the intracellular $\mathrm{Hg}$ concentration 
followed a decreasing trend, starting from the beginning of exposure to longer incubation times. Thus, at $[\mathrm{Hg}]=5 \mathrm{nM}$, the $[\mathrm{Hg}]_{\text {intr }}$ decreased from $20.6 \pm 2.8 \mathrm{amol} \mathrm{cell}^{-1}$ on the $1^{\text {st }}$ day, to $6.6 \pm 1.1$ amol cell ${ }^{-1}$ on the $7^{\text {th }}$ day of exposure. This trend can be due, at least in part, to dilution by cell duplication, nevertheless the occurrence of a process of loss of $\mathrm{Hg}$ cannot be excluded. In the literature it has been reported that aquatic microorganisms, mainly bacteria but also eukaryotic phytoplankton, are capable of transforming ionic $\mathrm{Hg}$ to volatile $\mathrm{Hg}$ species, thus the existence of a similar process of $\mathrm{Hg}$ transformation could contribute, in our experimental conditions, to the lowering of the $[\mathrm{Hg}]_{\text {intr. }}$

\subsection{Production of DGM in cultures of T. weissflogii}

The ability of the marine diatom $\underline{\mathrm{T}}$. weissflogii to produce volatile $\mathrm{Hg}$ species was assayed by carrying out direct measurements of DGM production in an exponentially growing culture of this diatom, previously spiked with mercury $([\mathrm{Hg}]=5 \mathrm{nM})$. The pattern of $[\mathrm{Hg}]_{\text {diss }}$ in the presence and absence of cells, together with that of the $\mathrm{Hg}$ taken up by the cells $\left([\mathrm{Hg}]_{\text {cell }}\right)$, is reported in Fig. 4. The figure shows that the cell addition dramatically lowers the $[\mathrm{Hg}]_{\text {diss }}$ in solution, concomitantly with an increase in cellular density (see insert). As expected due to cell growth, the fraction of $\mathrm{Hg}$ associated to cells $\left([\mathrm{Hg}]_{\text {cell }}\right)$ increases with incubation time. Nevertheless it can be calculated that, during the exponential growth phase, this amount is not sufficient to explain the loss of $[\mathrm{Hg}]_{\text {diss }}$ in solution.

Measurements of DGM were performed both in the whole culture and in the culture medium after removal of cells by filtration, in order to isolate the biotic contribution to the mercury volatilization from the abiotic one, due to the culture medium. Samples were analyzed under dark and light conditions to compare the efficiency of the two DGM production processes. Table 1 shows the values of DGM production recorded on day 4 of growth of the culture of $\underline{T}$. weissflogii, by using both alive and formaldehyde-killed cells. The results show that a 
meaningful DGM production occurred both under dark and light conditions. The DGM production of the culture of $\underline{T}$. weissflogii with live cells was significantly higher than that measured in the culture medium alone, both in dark and light conditions. On the contrary, the DGM production of the culture with formaldehyde-killed cells exhibited values similar to those obtained after cell removal. These results clearly demonstrate the significant contribution of living cells in mercury volatilization. The DGM production in the culture medium was higher in the light compared to the dark, as expected from the contribution of the biogenic organic matter in photochemical reactions of $\mathrm{Hg}$ reduction (Costa and Liss, 1999; Lanzillotta et al., 2004). Our results also show that, in our experimental conditions, the contribution of the live cells to DGM production seems to be independent of the light, being $4.6 \pm 0.8 \mathrm{pmol} \mathrm{L}^{-1} \mathrm{~h}^{-1}$ in the light and $4.5 \pm 0.9 \mathrm{pmol} \mathrm{L}^{-1} \mathrm{~h}^{-1}$ in dark conditions. In order to strengthen the previous findings, we examined the relationship between the percentage of total dissolved mercury transformed in DGM by cells in $1 \mathrm{~h}$ (\%DGM) and the cellular density in solution, calculated at different times of growth of the culture of $\underline{T}$. weissflogii (see Fig. 4). Fig. 5 A-B shows a positive and significant correlation between the $\%$ DGM and cellular density, both in light and dark conditions $(\mathrm{p}<0.01)$. Moreover, we examined the relationship between the same \% DGM and the $[\mathrm{Hg}]_{\text {diss }}$ in the culture medium. In this case, no significant correlation was observed (Fig. 5 C-D). The strict dependence of the $\%$ DGM on the cellular density, and not on the $[\mathrm{Hg}]_{\text {diss }}$ in the culture medium, confirms the direct cellular contribution to the DGM production in the culture. Moreover, the similarity of the slopes of the regression lines in Fig. 5 A-B supports the finding that the direct contribution of living cells to DGM production was unaffected by the conditions of illumination. These findings are consistent with those of Devars et al. (2000) who found that the ability to volatilize mercury by the freshwater microalga Euglena gracilis was independent of light. 


\section{Discussion}

The marine diatom $\underline{T}$. weissflogii responded to mercury exposure with two distinct mechanisms: the increase of the non-protein thiol pool and the production of DGM. Our data show that the mercury treatment $(5-150 \mathrm{nM}, 2$ day- exposure) induced a general increase of the non-protein thiol pool: besides glutathione and $\gamma$-EC, which are constitutively expressed in the cell, HPLC analysis showed the occurrence of PC synthesis. Although it is well known that marine phytoplankton can synthesize PCs in response to a variety of metal ions (Ahner et al., 1995; Rijstenbil and Wijnholds, 1996; Morelli and Scarano 2001, 2004; Kawakami et al., 2006; Le Faucheur et al., 2006), systematic studies regarding their capability to synthesize PCs in response to mercury are lacking. Howe and Merchant (1992), in a study examining the ability of the green microalga Chlamydomonas reinhardtii to produce metalbinding peptides in response to $\mathrm{Cd}, \mathrm{Hg}$ or $\mathrm{Ag}$, reported that $\mathrm{Hg}$-treated cells exhibited a transient but striking increase in glutathione levels, but were not able to accumulate measurable amounts of PCs. Recently, much more information has become available on the effects of $\mathrm{Hg}$ on the non-protein thiol pool in plants (Gupta et al, 1998; Iglesia-Turino et al., 2006; Israr et al., 2006; Rellan-Alvarez et al., 2006). Among these authors, general agreement on the involvement of glutathione in $\mathrm{Hg}$ detoxification can be observed. Only one paper (Gupta et al., 1998) reports that, besides glutathione, PCs can play a role in the Hg cellular sequestration in two species of aquatic plants.

Our findings on the time course of the non-protein thiol pool show that glutathione and related peptides (PCs and $\boldsymbol{\gamma}$-EC) undergo a rapid synthesis followed by a slower decrease of their cellular concentration at longer exposure times. At the end of the exposure, only the level of PCs, but not that of glutathione and $\gamma$-EC, remained altered in the Hg-treated cells compared to the untreated ones. The restoring of glutathione to basal levels (comparable to those measured in the control culture) might imply the occurrence of a process of release of 
this thiol. Accordingly, Tang et al. (2005) demonstrated an extracellular release of glutathione by $\underline{T}$. weissflogii cells under copper stress. Our findings seem to suggest a mechanism in which the $\mathrm{Hg}$ taken up by the cells at the beginning of the exposure could form $\mathrm{Hg}-\mathrm{GSH}$ complexes which might subsequently transfer the metal ion into the newly formed PCs in order to form more stable Hg-PCs complexes. These, in turn, could be released and /or degraded more slowly. The occurrence of a similar mechanism for $\mathrm{Hg}$ sequestration is supported by an in vitro study demonstrating that GSH can transfer $\mathrm{Hg}$ into PCs at increasingly longer chain lengths (Mehra et al., 1996). The initial formation of metalglutathione complexes followed by a transfer to the metal-induced PCs has been also hypothesized to occur in Phaeodactylum tricornutum under $\mathrm{Cd}$ or $\mathrm{Cu}$ exposure (Morelli et al, 2002; Morelli and Scarano, 2004). In the present study, the substantial stability of the $[\mathrm{Hg}]_{\text {intr }}$ concomitant with a decrease of the PC concentration, along with the exposure time, doesn't exclude that other intracellular ligands might participate in the intracellular sequestration of the metal. In a recent paper, Kelly et al. (2007) reported that a number of eukaryotic algae were able to biotransform $\mathrm{Hg}(\mathrm{II})$ into $\beta-\mathrm{HgS}$ at varying degrees and to accumulate this metal species in the cell. Further studies are needed to clarify this issue.

Our data show alterations of the non-protein thiol pool at $[\mathrm{Hg}]>5 \mathrm{nM}$, whereas at lower

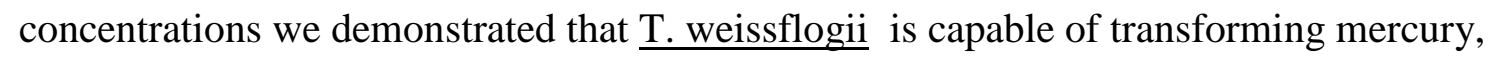
added as $\mathrm{HgCl}_{2}$, into volatile $\mathrm{Hg}$ species. Other authors have suggested that eukaryotic microorganisms, besides the prokaryotic ones, can reduce mercury, but only few authors measure DGM production directly. Ben-Bassat and Mayer (1978), Amyot et al. (1994) and Vandal et al. (1991) found a correlation between chlorophyll a concentration and $\mathrm{Hg}^{\circ}$ formation rate suggesting that there is a link between productivity and $\mathrm{Hg}$ reduction. Mason et al. (1995) carried out measurements of DGM production in laboratory monocultures of a number of phytoplankton species, including T. weissflogii, and demonstrated their capability 
of reducing $\mathrm{Hg}$ (II) to $\mathrm{Hg}^{\circ}$, although the rate of reduction was insufficient to account for the reduction rates observed in incubated field samples. The rate of DGM production measured by these authors in $\underline{\text { T } \text { weissflogii }}\left(0.29\right.$ amol cell $\left.^{-1} \mathrm{~d}^{-1}\right)$ was comparable to that measured in the present study $\left(2.6\right.$ amol cell $\left.{ }^{-1} \mathrm{~d}^{-1}\right)$ at similar cellular density $\left(5-7 \times 10^{7}\right.$ cell $\left.\mathrm{L}^{-1}\right)$, taking into account the ten-fold higher $[\mathrm{Hg}]$ which we used.

Very little has been found in the literature on the mechanisms involved in the $\mathrm{Hg}$ reduction in eukaryotic microorganisms. $\mathrm{Hg}^{\circ}$ production could involve cell surface reduction, similar to that found for other trace metals (Jones et al., 1987) rather than a gene encoded $\mathrm{Hg}$ resistance mechanism, as in the case of prokaryotic microorganisms. Ben-Bassat and Mayer (1977)

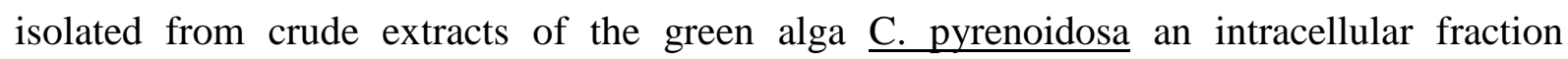
(molecular weight < $1200 \mathrm{Da}$ ) responsible for $\mathrm{Hg}$ reduction, but its nature remains unknown.

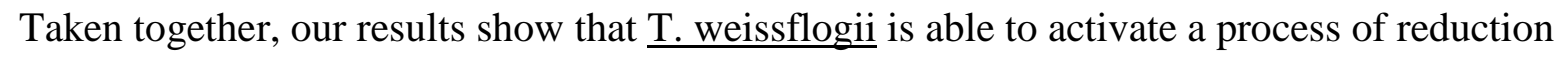
of $\mathrm{Hg}(\mathrm{II})$ to $\mathrm{Hg}^{\circ}$, producing measurable amounts of DGM when exposed even at low $\mathrm{Hg}$ concentrations $([\mathrm{Hg}]=5 \mathrm{nM})$. At higher $\mathrm{Hg}$ concentrations $([\mathrm{Hg}]=10-150 \mathrm{nM})$, the rate of DGM production seems to be insufficient to prevent $\mathrm{Hg}$ intracellular accumulation. In this case, the $\mathrm{Hg}$ accumulated by the cells would induce a general increases in the actual pool of glutathione and $\gamma$-EC, besides inducing an ex-novo synthesis of PCs.

\section{References}

Ahner BA, Kong S, Morel FMM. Phytochelatin production in marine algae. 1. An interspecies comparison. Limnol Oceanogr 1995; 40:649-657.

Ahner BA, Morel FMM. Phytochelatin production in marine algae. 2. Induction by various metals. Limnol Oceanogr 1995; 40:658-665. 
Amyot M, Mierle G, Lean D, McQueen D. Sunlight induced formation of dissolved gaseous mercury in lake waters. Environ Sci Technol 1994; 28:2366-2371.

Barkay T, Turner RR, Vandenbrook A, Liebert C. The relationship of $\mathrm{Hg}^{2+}$ volatilization from freshwater pond to the abundance of mer genes in the gene pool of the indigenous microbial community. Microb Ecol 1991; 21:151-161.

Barkay T, Miller SM, Summers AO. Bacterial mercury resistance from atoms to ecosystems. FEMS Microbiol Rev 2003; 27:355-384.

Barkay T, Wagner-Dobler I. Microbial transformations of mercury: Potentials, challenges, and achievements in controlling mercury toxicity in the environment. Adv Appl Microbiol 2005; 57:1-52.

Ben-Bassat D, Mayer AM. Volatilization of mercury by algae. Physiol Plant 1975; 33:128132.

Ben-Bassat D, Mayer AM. Reduction of mercury chloride by Chlorella: evidence for a reducing factor. Physiol Plant 1977; 40:157-162.

Ben-Bassat D, Mayer AM. Light-induced $\mathrm{Hg}$ volatilization and $\mathrm{O}_{2}$ evolution in Chlorella and the effect of DCMU and methylamine. Physiol Plant 1978; 42:33-38.

Cobbett CS. Phytochelatins and their roles in heavy metal detoxification. Plant Physiol 2000; 123:825-832.

Costa M, Liss P. Photoreduction of mercury in sea water and its possible implication for $\mathrm{Hg} 0$ air-sea fluxes. Mar Chem 1999; 68:87-95.

Devars S, Aviles C, Cervantes C, Moreno-Sanchez R. Mercury uptake and removal by Euglena gracilis. Arch Microbiol 2000; 174:175-180.

Fantozzi L, Ferrara R, Frontini FP, Dini F. Dissolved gaseous mercury production in the dark: Evidence for the fundamental role of bacteria in different types of Mediterranean water bodies. Sci Total Environ 2009; 407:917-924. 
Ferrara R, Lanzillotta E, Ceccarini C. Dissolved gaseous mercury concentration and mercury evasional flux from seawater in front of a chlor-alkali plant. Environ Technol $2001 ; 22: 971-978$.

Fokin SI, Di Giuseppe G, Erra F, Dini F. Euplotespora binucleata n. gen., n. sp. (Protozoa: Microsporidia), a parasite infecting the hypotrichous ciliate Euplotes woodruffi, with observations on microsporidian infections in ciliophora. J Eukaryot Microbiol 2008; $55: 214-228$.

Friederich M, Kneer R, Zenk MH. Enzymic synthesis of phytochelatins in gram quantities. Phytochem 1998; 49:2323-2329.

Gekeler W, Grill E, Winnacker EL, Zenk MH. Algae sequester heavy metals via synthesis of phytochelatin complexes. Arch Microbiol 1988; 150:197-202.

Grill E, Winnacker EL, Zenk MH. Phytochelatins: The principal heavy-metal complexing peptides of higher plants. Science 1985; 230:674-676.

Guillard RRL. Cultures of phytoplankton for feeding marine invertebrates. In: Smith WL, Chanley MH, editors. Culture of marine invertebrates animals. New York: Plenum Press $1975 ; 29-60$.

Gupta M, Tripathi RD, Rai UN, Chandra P. Role of glutathione and phytochelatin in Hydrilla verticillata Royal and Vallisneria spiralis L. under mercury stress. Chemosphere 1998; $37(4): 785-800$.

Horvat M, Kotnik J, Logar M, Fajon V, Zvonaric T, Pirrone N. Speciation of mercury in surface and deep-sea waters in the Mediterranean Sea. Atmos Environ 2003; 37:93108.

Howe G, Merchant S. Heavy metal-activated synthesis of peptides in Chlamydomonas reinhardtii. Plant Physiol 1992; 98:127-136. 
Iglesia-Turino S, Febrero A, Jauregui O, Caldelas C, Araus JL, Bort J. Detection and quantification of unbound phytochelatin 2 in plant extracts of Brassica napus grown with different levels of mercury. Plant Physiol 2006; 142:742-749.

Israr M, Sahi S, Datta R, Sarkar D. Bioaccumulation and physiological effects of mercury in Sesbania drummondii. Chemosphere 2006; 65:591-598.

Jones GJ, Palenik BP, Morel FMM. Trace metal reduction by phytoplankton: the role of plasmalemma redox enzimes. J Phycol 1987; 23:237-244.

Kawakami SK., Gledhill M, Achterberg EP. Production of phytochelatins and glutathione by marine phytoplankton in response to metal stress. J Phycol 2006; 42:975-989.

Kelly DJ, Budd K, Lefebvre DD. Biotransformation of mercury in pH-stat cultures of eukaryotic freshwater algae. Arch Microbiol 2007; 187(1):45-53.

Kneer R, Zenk MH. The formation of Cd-phytochelatin complexes in plant cell cultures. Phytochem 1997; 44:69-74.

Lanzillotta E, Ferrara R. Daily trend of dissolved gaseous mercury concentration in coastal seawater of the Mediterranean basin. Chemosphere 2001; 45:935-940.

Lanzillotta E, Ceccarini C, Ferrara R, Dini F, Frontini FP, Banchetti R. Importance of the biogenic organic matter in photo-formation of dissolved gaseous mercury in a culture of the marine diatom Chaetoceros sp. Sci Total Environ 2004; 318:211-221.

Lee JG, Ahner BA, Morel FMM. Export of cadmium and phytochelatin by the marine diatom Thalassiosira weissflogii. Environ Sci Technol 1996; 30:1814-1821.

Le Faucheur S, Schildknecht F, Behra R, Sigg L. Thiols in Scenedesmus vacuolatus upon exposure to metals and metalloids. Aquat Toxicol 2006; 80:355-361.

Mason RP, Morel FMM, Hemond HF. The role of microorganisms in elemental mercury formation in natural waters. Water, Air and Soil Poll 1995; 80:775-787. 
Medlin L, Elwood HJ, Stickel S, Sogin ML. The characterization of enzymatically amplified 16S-like rRNA-coding regions. Gene 1988; 71:491-499.

Mehra RK, Miclat J, Kodati R, Abdullah R, Hunter TC, Mulchandani P. Optical spectroscopic and reverse-phase HPLC analysis of $\mathrm{Hg}^{2+}$ binding to phytochelatins. Biochem J 1996; 314:73-82.

Morelli E, Scarano G. Synthesis and stability of phytochelatins induced by cadmium and lead in the marine diatom Phaeodactylum tricornutum. Mar Environ Res 2001; 52:383-395.

Morelli E, Cruz BH, Somovigo S, Scarano G. Speciation of cadmium- $\gamma$-glutamyl peptides complexes in cells of the marine microalga Phaeodactylum tricornutum. Plant Sci $2002 ; 163: 807-813$.

Morelli E, Scarano G. Copper-induced changes of non-protein thiols and antioxidant enzymes in the marine microalga Phaeodactylum tricornutum. Plant Sci 2004; 167:289-296.

Nakamura K, Iwahara M, Furukawa K. Screening of organomercurial-volatilizing bacteria in the mercury-polluted sediments and seawater of Minamata Bay in Japan. Clean Prod Processes 2001; 3:104-107.

Perales-Vela HV, Peña-Castro JN, Cañizares-Villanueva RO. Heavy metal detoxification in eukaryotic microalgae. Chemosphere 2006; 64:1-10.

Petroni G, Dini F, Verni F, Rosati G. A molecular approach to the tangled intrageneric relationships underlying phylogeny in Euplotes (Ciliophora, Spirotrichea). Mol. Phylogenet Evol 2002; 22:118-130.

Pinto E, Sigaud-Kutner TCS, Leitão MAS, Okamoto OK, Morse D, Colepicolo P. Heavy metal-induced oxidative stress in algae. J Phycol 2003; 39:1008-1018.

Poulain A J, Amyot M, Findlay D, Telor S, Barkay T, Hintelmann H. Biological and photochemical production of dissolved gaseous mercury in a boreal lake. Limnol Oceanogr 2004; 49:2265-2275. 
Rauser WE. Phytochelatins and related peptides. Structure, biosynthesis and function. Plant Physiol 1995; 109:1141-1149.

Rellan-Alvarez R, Ortega-Villasante C, Alvarez-Fernandez A, del Campo FF, Hernandez LE. Stress responses of Zea mays to cadmium and mercury. Plant and Soil 2006; 279:4150.

Rijstenbil JW, Wijnholds JA. HPLC analysis of non-protein thiols in planktonic diatoms: pool size, redox state and response to copper and cadmium exposure. Mar Biol 1996; $127: 45-54$

Rolfhus KR, Fitzgerald WF. Mechanisms and temporal variability of dissolved gaseous mercury production in coastal seawater. Mar Chem 2004; 90:125-136.

Sambrook, J., Fritsch, E.F. \& Maniatis, T. Molecular Cloning: A Laboratory Manual. 2nd ed. Cold Spring Harbor Laboratory Press, Cold Spring Harbor, NY 1989.

Schroeder WH, Munthe J, Lindqvist O. Cycling of mercury between water, air and soil compartments of the environment. Water, Air and Soil Poll 1989; 48: 337-347.

Tang D, Shafer MM, Karner DA, Armstrong DE. Response of non-protein thiols to copper stress and extracellular release of glutathione in the diatom Thalassiosira weissflogii. Limnol Oceanogr 2005; 50(2):516-525.

Vandal GM, Mason RP, Fitzgerald WF. Cycling of volatile mercury in temperate lakes. Water, Air and Soil Poll 1991; 56:791-803.

Zenk MH. Heavy metals detoxification in higher plants - a review. Gene 1996; 179:21-30. 


\section{Figure captions}

Figure 1. Percentage of inhibition of growth rate $\left(\mu\right.$, doublings day $\left.{ }^{-1}\right)$ of $\underline{\text { T. weissflogii }}$ cultures under mercury exposure. Initial cell density $=10^{6}$ cells $\mathrm{L}^{-1}$. Exposure time $=6$ days. Different symbols refer to two independent experiments.

Figure 2. Patterns of glutathione $(\circ), \boldsymbol{\gamma}$-EC $(\boldsymbol{\nabla}), \mathrm{PCs}(\bullet)$ and $[\mathrm{Hg}]_{\text {intr }}(\Delta)$ in $\underline{\mathrm{T} \text {. weissflogii }}$ cells exposed for 2 days to increasing $\mathrm{Hg}$ concentrations. Initial cell density $=10^{6}$ cells $\mathrm{L}^{-1}$. Standard deviations refer to duplicate experiments.

Figure 3. Time course of the intracellular $\mathrm{Hg}$ concentration and of the non-protein thiol pool in $\underline{\mathrm{T}}$. weissflogii cells exposed to $150 \mathrm{nM} \mathrm{Hg}$ for 7 days. PC concentration is expressed as the sum of the $\gamma$-Glu-Cys units. Initial cell density $=10^{6}$ cells $\mathrm{L}^{-1}$. Standard deviations refer to duplicate experiments.

Figure 4. Time course of the total dissolved $\mathrm{Hg}$ concentration measured in the culture

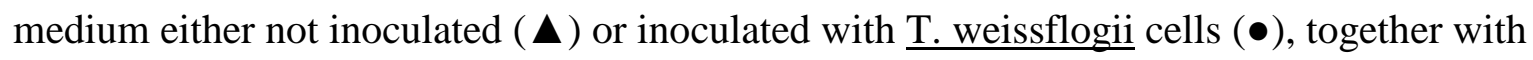
the cell-bound $\mathrm{Hg}$ concentration (०). Culture media contained $5 \mathrm{nM} \mathrm{HgCl}_{2}$ and were let equilibrate for 3 days before inoculum. Standard deviations refer to triplicate experiments. Insert: growth curve of the $\underline{T}$. weissflogii culture used for the experiment.

Figure 5. Correlation between the percentage of total dissolved mercury transformed into DGM by cells in $1 \mathrm{~h}(\% \mathrm{DGM})$ vs. cellular density (A-B) or vs. $[\mathrm{Hg}]_{\text {diss }}$ in the medium (C-D), measured in a culture of $\underline{T}$. weissflogii exposed to mercury (culture conditions are reported in 
the caption of Fig.4). All the DGM production rates are corrected for the abiotic production of the culture medium. 


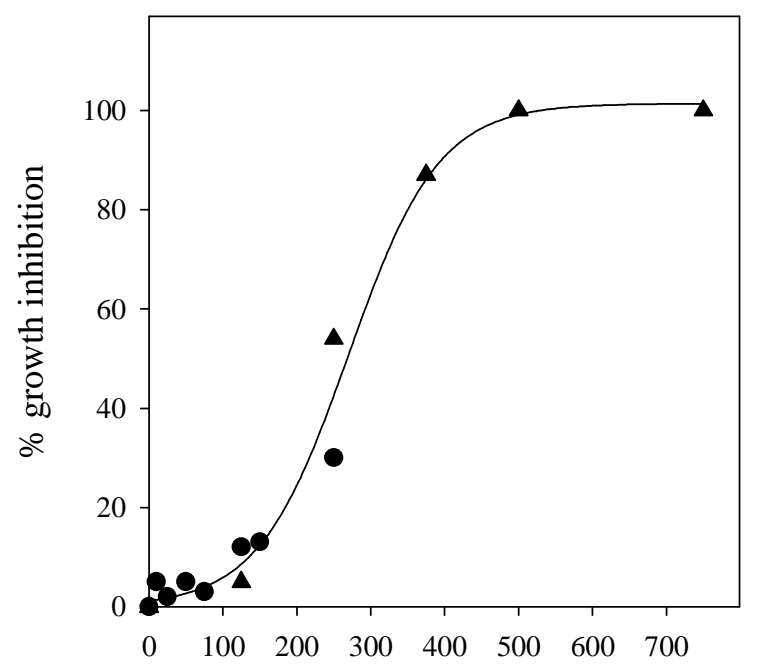

[Hg], (nM)

Figure 1 


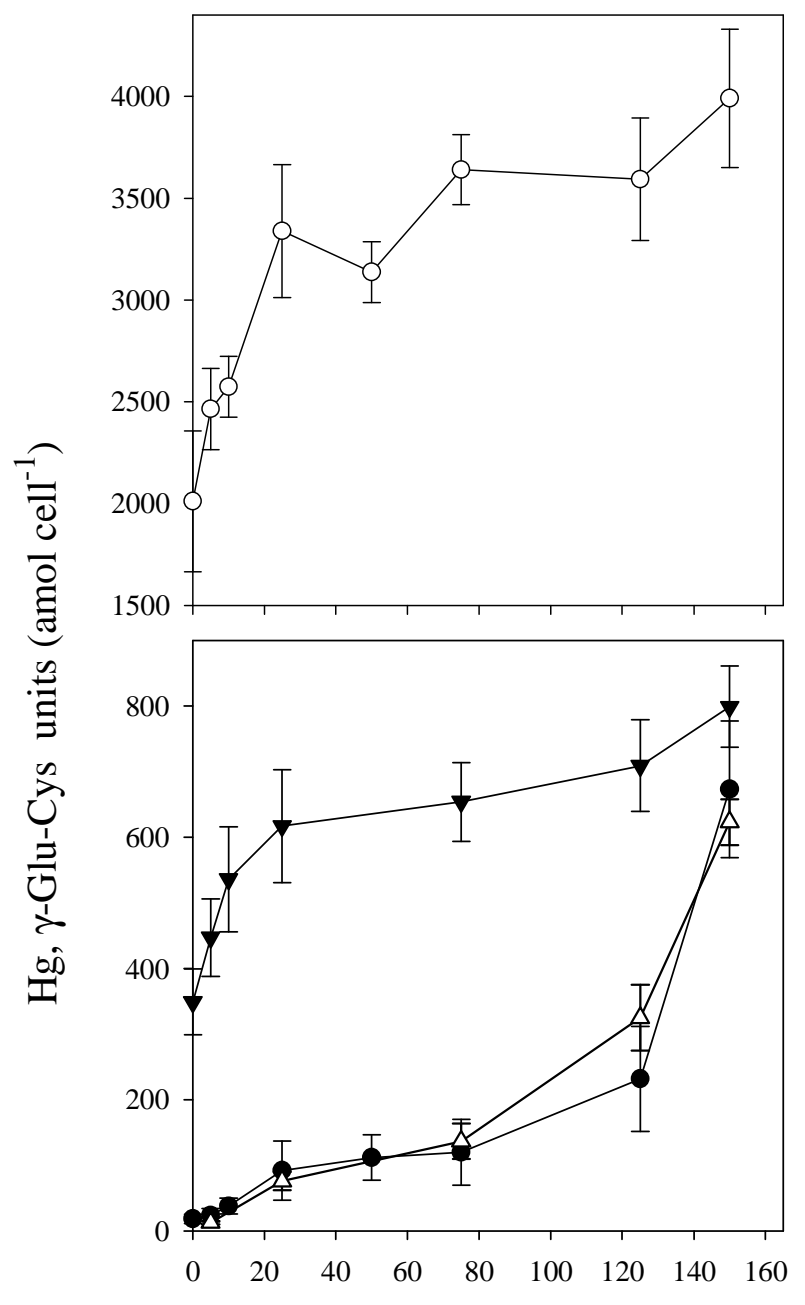

[Hg], (nM)

Figure 2 


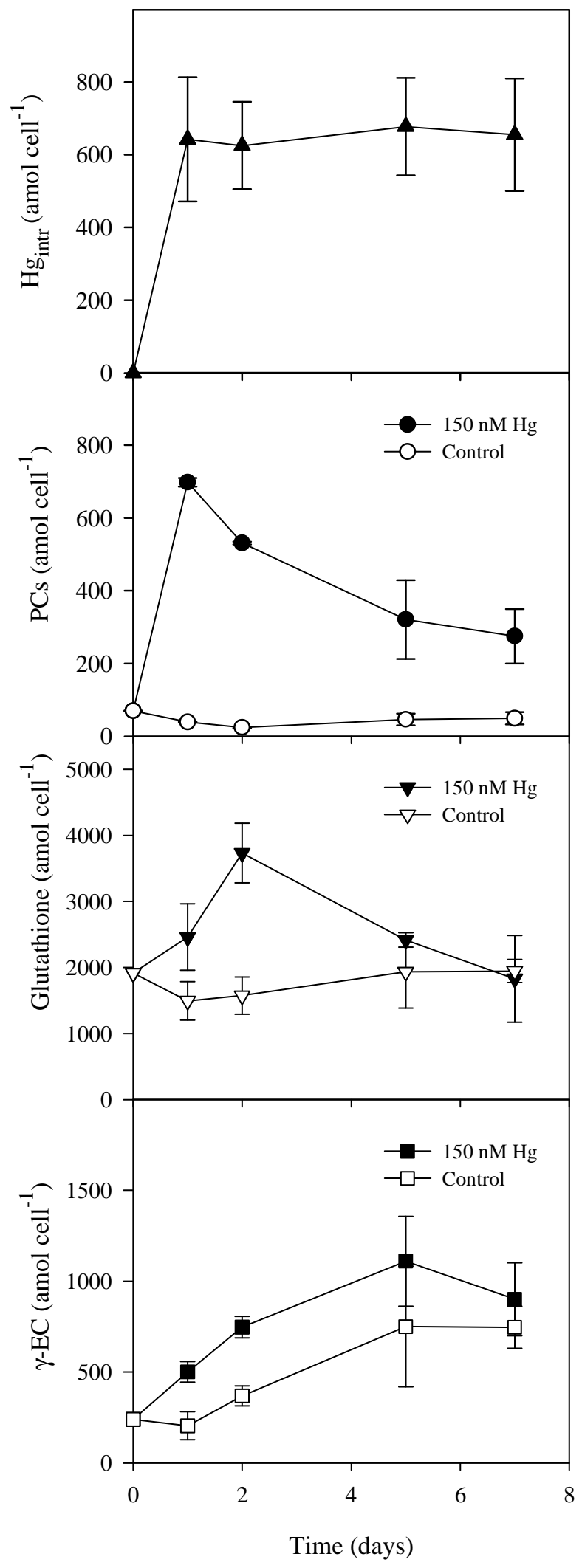

Figure 3 


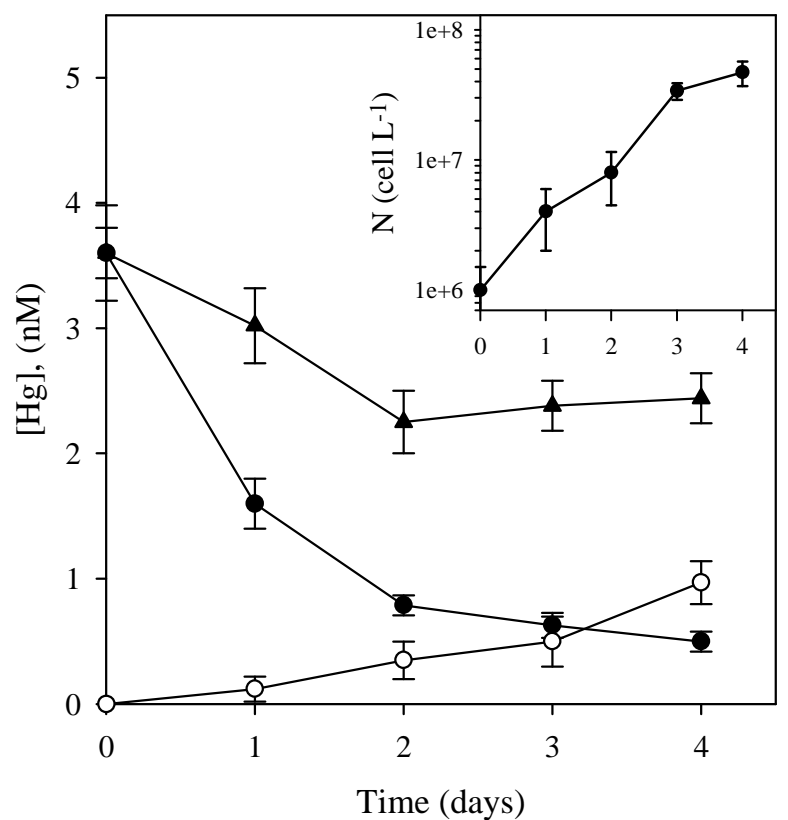

Figure 4 

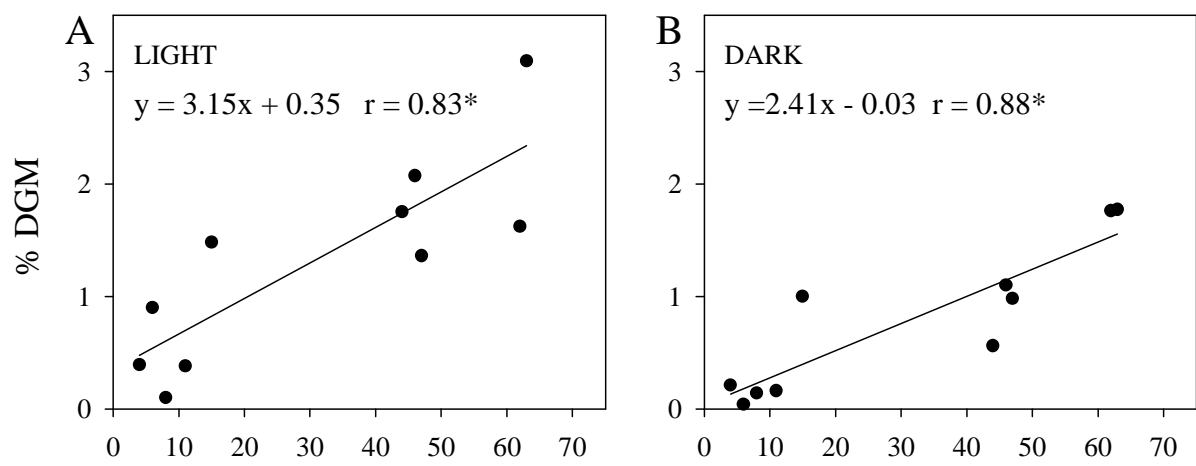

Cellular density $\left(10^{6}\right.$ cells L $\left.\mathrm{L}^{-1}\right)$
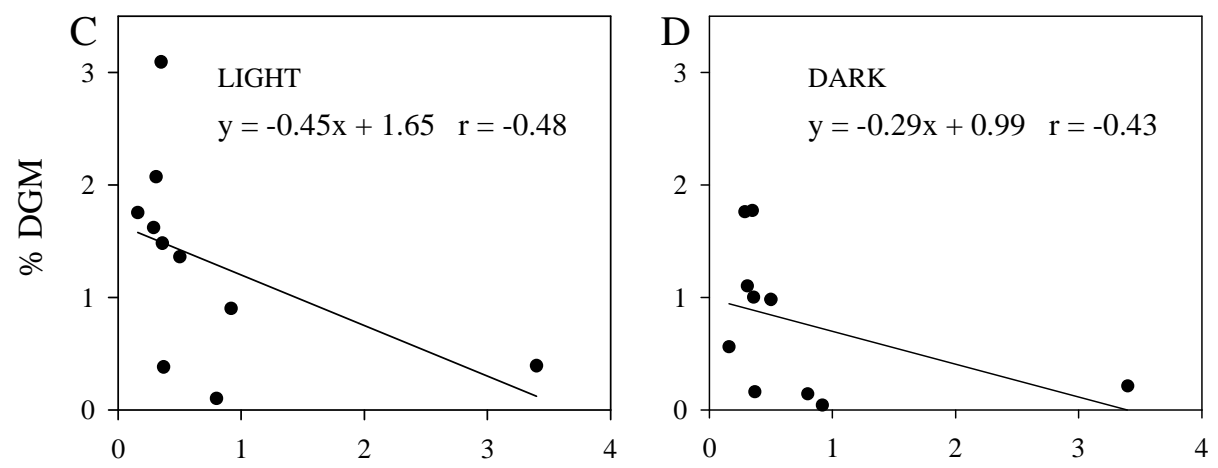

$[\mathrm{Hg}]_{\text {diss }}(\mathrm{nM})$

Figure 5 
Table 1. DGM production in cultures of $\underline{T}$. weissflogii containing either live or formaldehyde-killed cells, as well as in the culture medium after removing cells. Cells were grown for 4 days in a culture medium with $5 \mathrm{nM} \mathrm{HgCl}_{2}$. Cell density $=4-5 \times 10^{7}$ cell $\mathrm{L}^{-1}$.

The experiment was carried out in duplicate.

\begin{tabular}{lcc}
\hline & \multicolumn{2}{c}{ DGM $\left(\mathrm{pmol} \mathrm{L}^{-1} \mathrm{~h}^{-1}\right)$} \\
\cline { 2 - 3 } & Light & Dark \\
\hline Culture with live cells (1) & $8.7 \pm 0.8$ & $4.7 \pm 1.8$ \\
Culture with killed cells (2) & $4.6 \pm 0.7$ & $0.3 \pm 0.2$ \\
Culture medium (3) & $4.1 \pm 0.9$ & $0.2 \pm 0.1$ \\
Live cells (1)-(3) & $4.6 \pm 0.8$ & $4.5 \pm 0.9$ \\
Killed cells (2)-(3) & $0.5 \pm 0.7$ & $0.1 \pm 0.2$ \\
\hline
\end{tabular}

